\title{
転造加工を施した焼結鋼の抵抗率と比透磁率分布
}

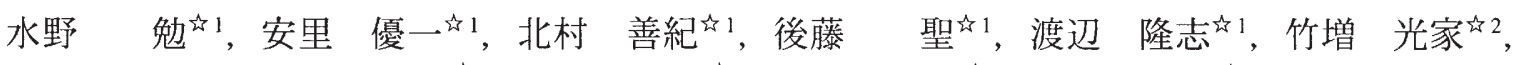

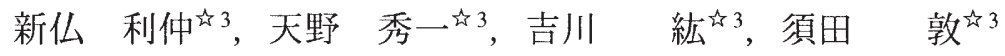 \\ 4 1 信州大学工学部電気電子工学科, 干 380-8553 長野市若里 4-17-1. \\ 的 2 諏訪東京理科大学システム工学部機械システム工学科, † 391-0292 茅野市豊平 5000-1. \\ 约3 株) ニッセ一, ₹ 409-0502 大月市富浜町鳥沢 2022.
}

\section{Distributions of Resistivity and Relative Permeability in Surface Rolled Sintered Steel}

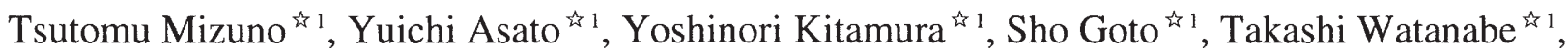 \\ Teruie Takemasu ${ }^{\text {मे } 2}$, Toshinaka Shinbutsu ${ }^{\text {मे } 3}$, Shuichi Amano ${ }^{\text {th } 3}$,

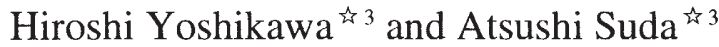 \\ 4 1 Electrical and Electronic Engineering, Faculty of Engineering, Shinshu University, 4-17-1 Wakasato, Nagano 380-8553, Japan. \\ ${ }^{i t}$ Department of Mechanical Systems Engineering, Faculty of Systems Engineering, Tokyo University of Science, Suwa, \\ 5000-1 Toyohira, Chino 391-0213, Japan. \\ ${ }^{4}{ }^{3}$ Nissei Co., Ltd., 2022 Torisawa, Tomihama-machi, Otsuki 409-0502, Japan.
}

Received December 15, 2011

\section{SYNOPSIS}

Surface rolled sintered gears are expected to be used in automotives. For commercialization of them, a reliable and efficient in-line inspection after rolling is inevitable. The authors have been proposing an eddy current inspection for PM components as a non-destructive, efficient method to be installed in-line. The eddy current depends on the resistivity and the relative permeability of the material to be measured. While those of sintered bodies will be changed by surface rolling as it will accompany with both the densification and the residual stress. In order to use the eddy current method as the inspection of the surface rolled sintered gear, distributions of the resistivity, the relative permeability along with the porosity of the $\mathrm{Fe}-1.5 \mathrm{Cr}-0.2 \mathrm{Mo}-0.23 \mathrm{C}$ alloy having 4 different densities, $7.0,7.25,7.5$ and 7.6 , were measured and analyzed.

\section{KEY WORDS}

sintered steel, form rolling, eddy current, resistivity, relative permeability

\section{1 まえがき}

転造加工した焼結歯車は材料の無䭾がなく安価に大量生産 できる1).そのために, 自動車トランスミッション用歯車と して期待されている ${ }^{2,3)}$. しかし, 転造が不十分であると強度 が低下する4), 過度な転造を施すとヒビや剥離が生じやすい, などの問題があり, 焼結歯車の良否判定が望まれている.

従来, 焼結転造体の良否判定をするためには, (1)歯車を切 断する破壊検查, (2)超音波, X線回析などを用いた非破壊検 査が用いら扎いる ${ }^{5,6)}$. しかし, 上記 (1)の方法は破壊検査 方法であるために, 全ての歯車の良否判定は不可能である. また, 上記(2)の方法は高価な測定機器を用いる, 測定に時間 を要する, などの問題がある. 転造加工によって表面からの 深さ約 $2.5 \mathrm{~mm}$ までの領域の気孔が潰されることが明らかに なっており7), 表面からの深さ $1 \mathrm{~mm}$ 以上の非破壊検査が可能 な良否判定方法が要求されている。
そこで, 著者らは渦電流非破壞検査を用いた転造加工した 焼結歯車の良否判定を提案している ${ }^{8,9)}$. 渦電流非破壊検査は 測定対象を非破壊かつ短時間で測定が可能である ${ }^{10)}$. そのた めに, 歯車の歯の全数検査が可能であり, インラインでの良 否判定ができる.さらに, 励振周波数を調節することでミリ オーダの深さまで非破壊検査が可能である.

渦電流非破壊検査における渦電流は測定対象の抵抗率およ び比透磁率に依存する ${ }^{10)}$. 磁性材料は残留応力や気孔率に依 存して抵抗率と比透磁率の両者ともに変化することが知られ ている ${ }^{11-13)}$. また, 軟磁性材用として使用されている, 純鉄 系, $\mathrm{Fe}-\mathrm{P}$ 系, $\mathrm{Fe}-\mathrm{Si}$ 系, 45パーマロイなどは, 比透磁率の気 孔率依存性が知られている ${ }^{14)}$. しかし, 自動車のトランス ミッション用歯車の材料として用いることが期待されている 焼結材における, 残留応力や気孔率に依存する抵抗率および 比透磁率は知られていない. 渦電流非破壞検査のために, こ 
れらの特性を知ることができれば, 非破壞検査の精度が向上 する, 測定速度の向上によるインラインテスト方法の開発に 繋がる.さらに, 転造シミュレーションの実証方法の一つと しての渦電流非破壊検査の活用が期待できる.

そこで本論文では, 焼結転造体の表面からの深さに依存す る気孔率, 残留応力, 抵抗率, 比透磁率について述べる.さ らに, 残留応力に依存する気孔率, 抵抗率, 比透磁率につい て考察する。

本論文では以下の事項について述べる.

(1) 表面からの深さに依存する気孔率, 残留応力, 抵抗率, 比 透磁率

(2) 残留応力に依存する気孔率, 抵抗率, 比透磁率

\section{2 測定試料および測定方法}

\section{1 测定試料}

測定試料にはへガネス $\mathrm{AB}$ 社が開発した $1.5 \mathrm{Cr}-0.2 \mathrm{Mo}$ 焼結 合金鋼の焼結素材を用いた. Table 1 に焼結素材の化学的構 成, Table 2 に気孔率, 密度, 硬さの特性をそれぞれ示した. いずれの素材も同じFe-1.5Cr-0.2Mo (mass\%)の完全合金化粉 に 0.23 mass\%の黒鉛を添加した原料粉末 (へガネス $\mathrm{AB}$ 社製) から, 1 回圧縮 1 回焼結の工程 (成形プレス圧力と焼結温度は 異なる)により円盤状に成形した。 加工硬化を抑え, 転造に よる表面層緻密化特性を改善するために, 素材の炭素含有量 は低く設定した。

それらの円盤状素材から削り出して作られた, 焼結転造体 の形状寸法をFig. 1 に示した。本論文では(侏)ニッセ一製の 2 ローラダイス回転軸移動式数值制御成形転造盤FA-20/CNCを

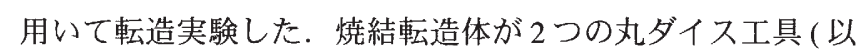
降, 工具と略記) に挟まれて転がりすべり接触しながら表面
転造されている. 加工は両工具軸を同期回転させながら, 軸 は固定で, 片側のみを一定速度で素材に対して半径方向に押 し込んだ.この工具押込み量が設定値に達した後, 規定時間 その状態を保持(ドウェル運軽と呼ぶ)して終了させた. また 工具押し込み量は表面からの深さ $0.5 \mathrm{~mm}$ までの気孔が十分に 潰されるように設定した7). なお潤滑剤には出光興産(制製の 汎用プレス油LF-7を用いた。

2.2 测定方法

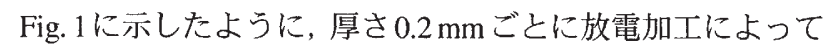
抵抗率測定用試料, 比透磁率測定用試料を作製した. 拡大図 に示した気孔率測定試料は, 原点 $\mathrm{O}$ と対称な位置においても

Table 1 Chemical composition (wt\%) of PM materials.

\begin{tabular}{l|c|c|c|c|c|c}
\hline Product name & $\mathrm{C}$ & $\mathrm{Ni}$ & $\mathrm{Mo}$ & $\mathrm{Cr}$ & $\mathrm{Cu}$ & $\mathrm{Fe}$ \\
\hline Astaloy CrL & 0.23 & - & 0.20 & 1.50 & - & Bal. \\
\hline
\end{tabular}

Table 2 Comparison of PM material characteristics.

\begin{tabular}{|c|c|c|c|c|c|}
\hline $\begin{array}{l}\text { Material } \\
\text { number }\end{array}$ & \multicolumn{2}{|c|}{ Product name } & $\begin{array}{c}\text { Core } \\
\text { density } \\
\left(\mathrm{g} / \mathrm{cm}^{3}\right)\end{array}$ & $\begin{array}{c}\text { Porosity } \\
(\%)\end{array}$ & $\begin{array}{c}\text { Hardness } \\
\text { (HRB) }\end{array}$ \\
\hline As- 7.00 & \multirow{4}{*}{$\begin{array}{c}\text { Astaloy } \\
\text { CrL }\end{array}$} & & 7.00 & 10.3 & 30 \\
\hline As- 7.25 & & & 7.25 & 7.1 & 45 \\
\hline $\mathrm{Hi}-7.50$ & & \multirow{2}{*}{ Hipaloy } & 7.50 & 3.8 & 59 \\
\hline $\mathrm{Hi}-7.60$ & & & 7.60 & 3.2 & 68 \\
\hline
\end{tabular}

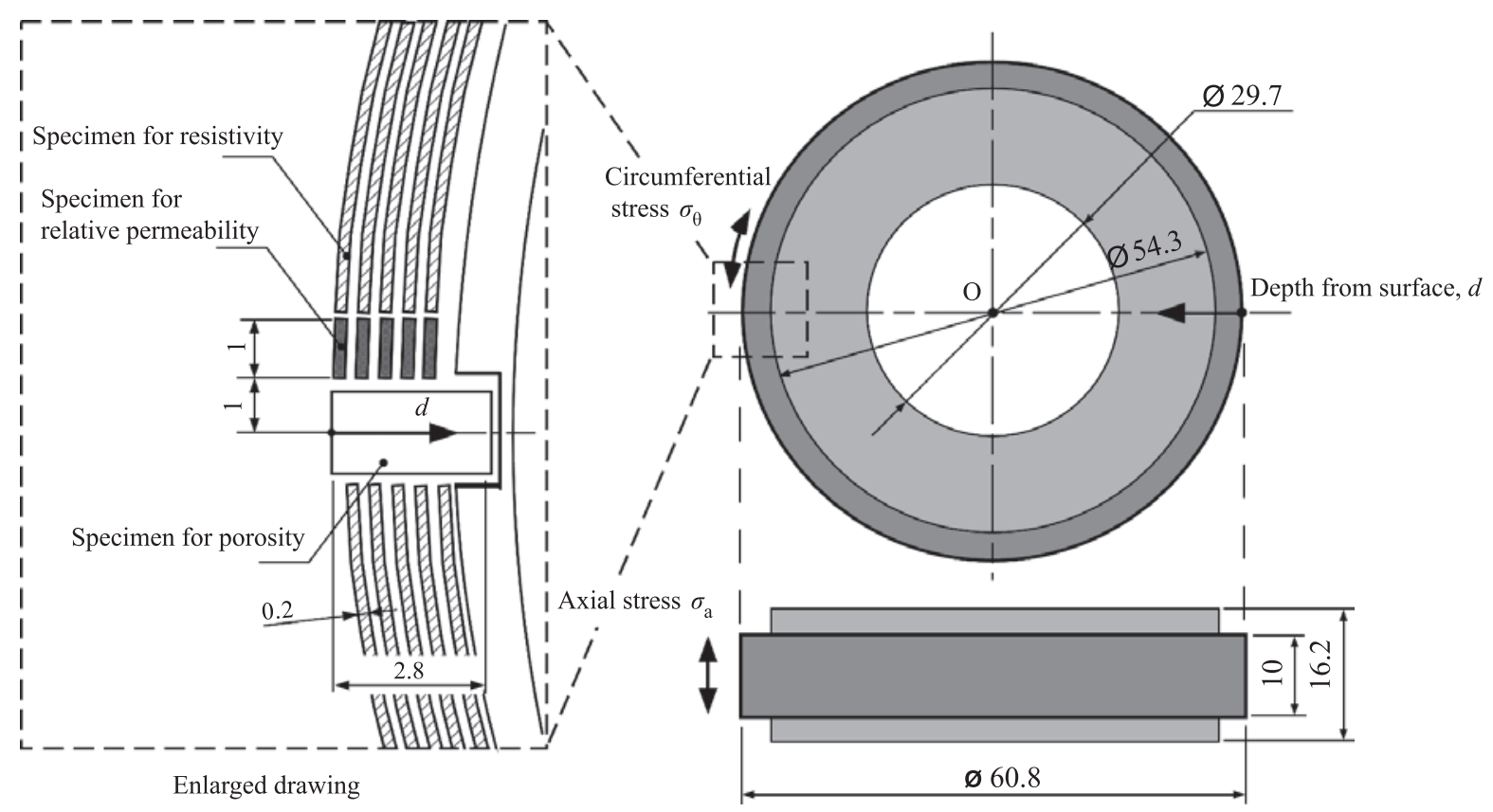

Fig. 1 Specimens for porosity, resistivity and relative permeability (unit: $\mathrm{mm}$ ). 
切り出した. すなわち, 気孔率測定試料は計 2 個, 抵抗率測 定試料と比透磁率測定試料はそれぞれ計 10 個である.なお, 気孔率測定試料は樹脂埋めして, 専用の電解研磨装置を用い て研磨した。研磨により閉塞した気孔の復元は, そのエッジ 部分を選択的に溶解できるよう電流密度を調整した。

2.2 .1 気孔率 $P$-表面からの深さ $d$ 特性

レーザ顕微鏡 (OLYMPUS, OLS-4000)を用いて表面からの 深さ $d$ に依存する気孔を観察した. 顕微鏡観察倍率の決定に ついては, 焦点深度と倍率を変えて, 最適な組み合わせを選 んだ. 画像処理を用いた気孔率の計算は, 組織観察領域の断 面写真を二值化処理し，黒と判定された画素を気孔として, その部分の面積率を各深さで求めることにより行った. すな わち, Fig. 2 (a) に示したように $0.1 \times 2.56 \mathrm{~mm}$ の抽出範囲面積 $A_{\mathrm{t}}$ と気孔の総面積 $A_{v}$ を用いて気孔率 $P$ を次式より算出した.

$$
P=\frac{A_{\mathrm{v}}}{A_{\mathrm{t}}} \times 100 \quad(\%)
$$

\section{2 .2 応力 $\sigma$-表面からの深さ $d$ 特性}

Fig. 1に示した焼結転造体と同一条件で作製した焼結転造体 を $0.2 \mathrm{~mm}$ ごとに電解エッチングを施して, 軸方向の応力 $\sigma_{\mathrm{a}}$, 円周方向の応力 $\sigma_{\theta}$ をそれぞれ測定した. なお, 測定にはX線 応力測定装置 (リガク製 PSPC-MSF-3M) を用いた.

2.2 .3 抵抗率 $\rho$-表面からの深さ $d$ 特性

ディジタルナノボルト・マイクロオームメータ (Agilent, AG34420A)を用いて試料の長さににおける抵抗 $R$ を測定した. その結果を用いて抵抗率 $\rho$ を下式より求めた.

$$
\rho=R \frac{A}{l} \quad(\Omega \cdot \mathrm{m})
$$

ここに, $A$ : 断面積 $\left(=2.0 \times 10^{-6} \mathrm{~m}^{2}\right)$

2.2.4 比透磁率 $\mu_{\mathrm{r}}$-表面からの深さ $d$ 特性

試料振動型磁力計 (VSM, 理研電子, BHV-55) を用いて試 料のB-Hループを測定した. 渦電流非破壊検査法を用いた良 否判定では, コイルによって磁界の強さ $H= \pm 320 \mathrm{~A} / \mathrm{m}$ を歯車 に作用させている ${ }^{8)}$. そのために $H= \pm 320 \mathrm{~A} / \mathrm{m}$ を作用させた ときの軸方向の比透磁率 $\mu_{\mathrm{r}}$ を下式を用いて求めた.

$$
\begin{aligned}
& \mu_{\mathrm{r}}=\frac{B}{\mu_{0} H} \\
& \text { ここに, } \mu_{0}: \text { 真空の透磁率 }\left(=4 \pi \times 10^{-7}, \mathrm{H} / \mathrm{m}\right)
\end{aligned}
$$

\section{3 測定結果}

3.1 気孔率 $P$-表面からの深さ $d$ 特性

Fig. 2 は各素材の表面からの深さ $d$ に依存する気孔である. 転造加工によって表面が緻密化されている。 また，Fig. 2 (a) に示したように, 素材の密度が小さいAs-7.00は他の素材と 比較すると気孔が多く観測された.

Fig. 3は式(1)を用いて算出した気孔率 $P$-表面からの深さ $d$ 特性である.なお， 2 個の試料の気孔率 $P$ をそれぞれ算出し て, その平均値をFig. 3 に示した. 表面からの深さ $d$ の増加に ともなって, 気孔率 $P$ は単調増加した. 転造加工によって表 面からの深さ約 $2.5 \mathrm{~mm}$ までの領域の気孔率が減少することが すでに検証されている。また, 緻密化の影響がおよばないと

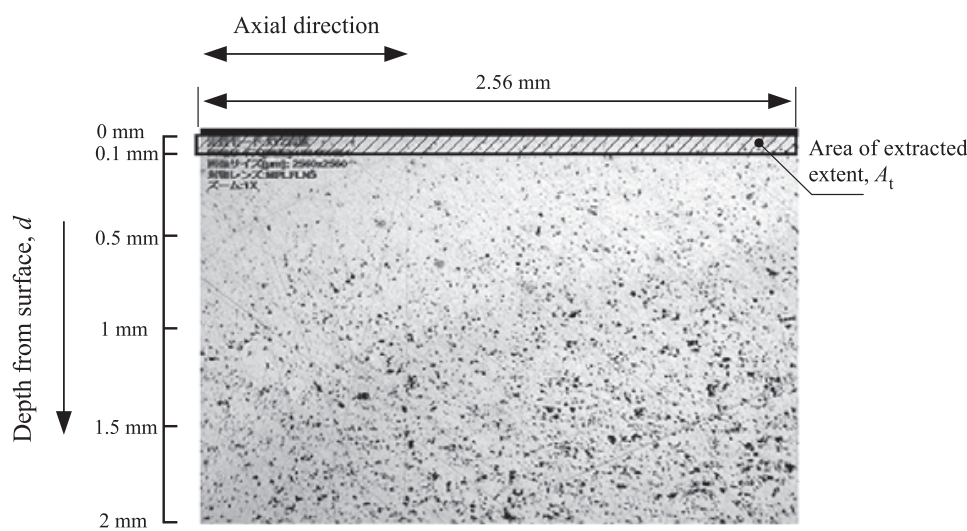

(a)

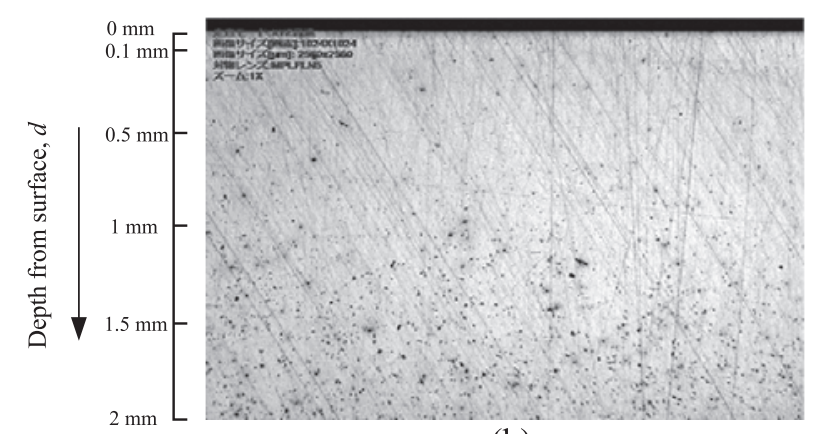

(b)

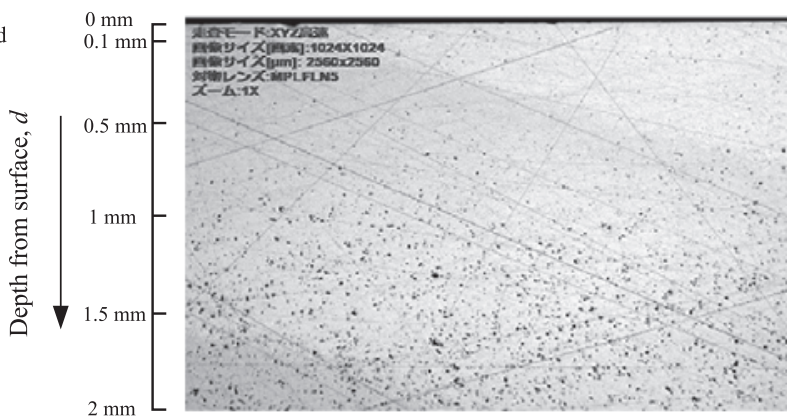

(c)

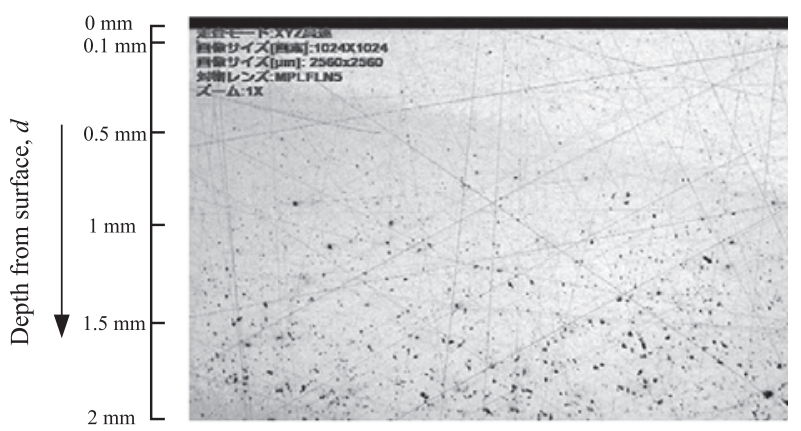

(d)

Fig. 2 Pore which depends on depth from surface of (a) As-7.00, (b) As-7.25, (c) Hi-7.50 and (d) Hi-7.60. 


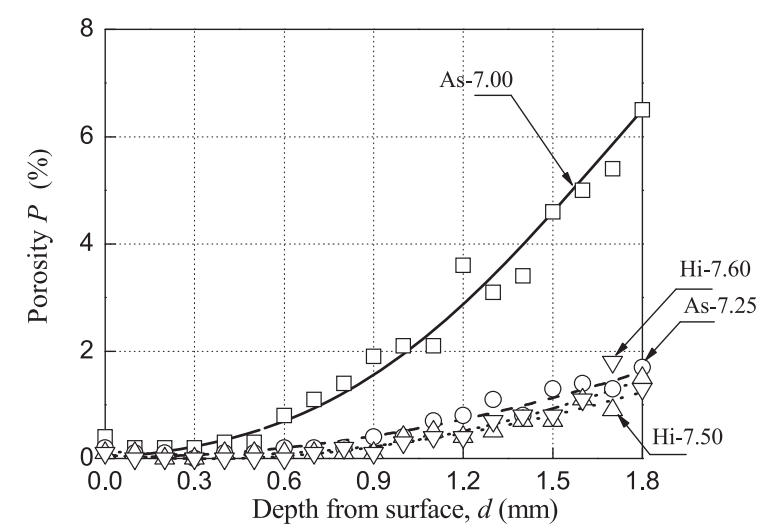

Fig. 3 Porosity-depth from surface characteristics as the parameter of PM materials.

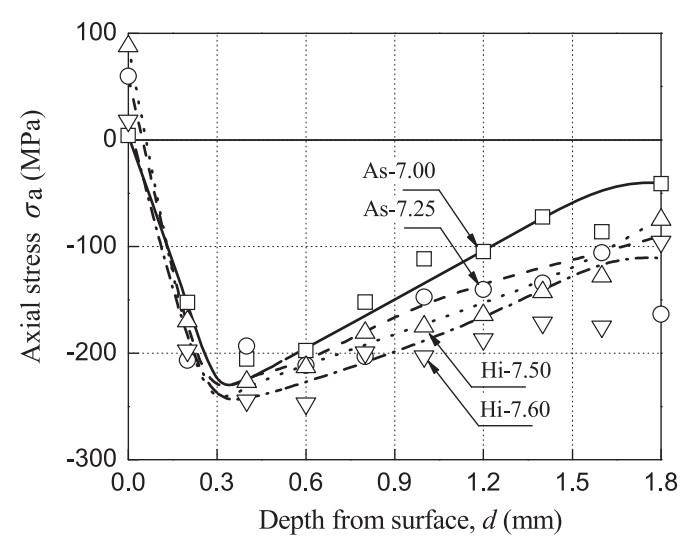

(a)

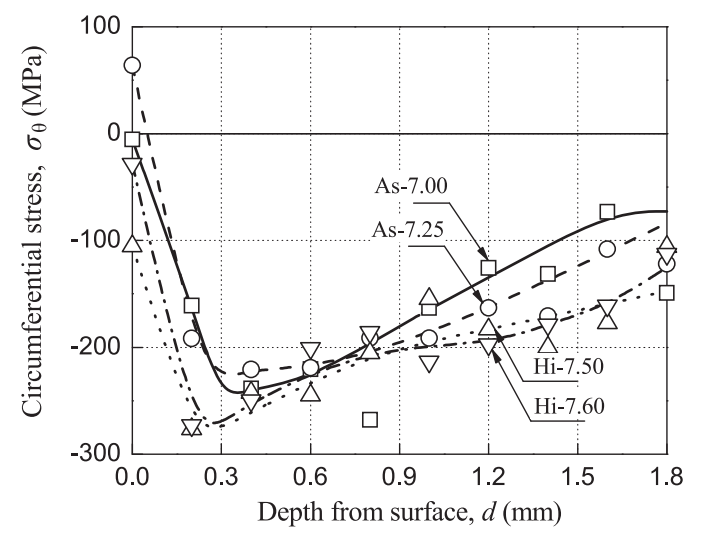

(b)

Fig. 4 Stress-depth from surface characteristics as the parameter of PM materials. (a) axial stress and (b) circumferential stress.

思われる $d=2.8 \mathrm{~mm}$ まで外挿すると, 各素材とも, メ一力発 表のアルキメデス法による気孔率と一致する.

\section{2 応力 $\sigma$-表面からの深さ $d$ 特性}

Fig. 4 (a) 法軸方向の応力 $\sigma_{\mathrm{a}}$-表面からの深さ $d$ 特性であり, Fig. 4 (b) は円周方向の応力 $\sigma_{\theta}$-表面からの哚さ $d$ 特性である. $d=0 \mathrm{~mm}-0.2 \mathrm{~mm}$ の範囲において $d$ の増加にともなつて残留応 力が高くなり, $d=0.2-0.4 \mathrm{~mm}$ 範囲において残留応力が最大

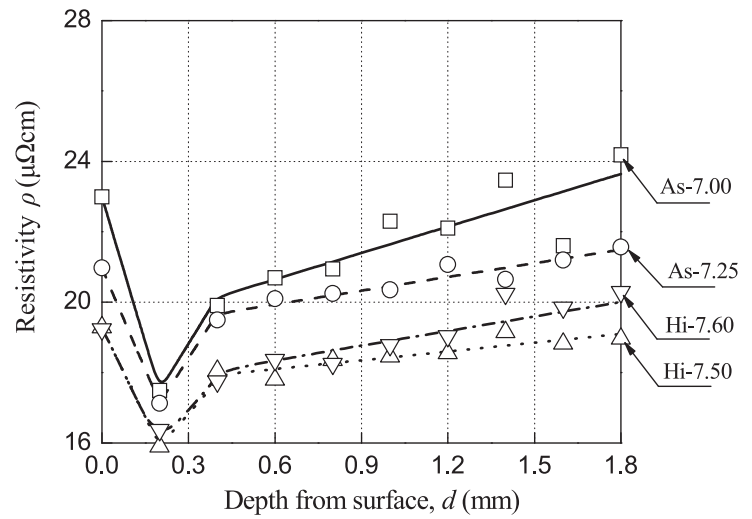

Fig. 5 Resistivity-depth from surface characteristics as the parameter of PM materials.

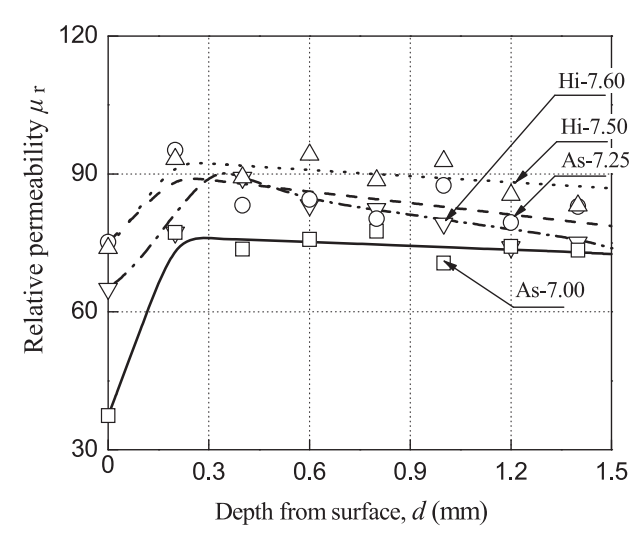

Fig. 6 Relative permeability-depth from surface characteristics as the parameter of PM materials.

になった. $d=0.4 \mathrm{~mm}$ 以降は残留応力が減少した. また, 素材 の密度が高くなるにしたがって (As-7.00 $\rightarrow$ As-7.25 $\rightarrow \mathrm{Hi}-7.50$ $\rightarrow \mathrm{Hi}-7.60)$, 残留応力も大きくなった. また, $d=0.4 \mathrm{~mm}$ にお いて軸方向の残留応力は円周方向の残留応力よりも $20 \mathrm{MPa}$ さくなった.

3.3 抵抗率 $\rho$-表面からの梁さ $d$ 特性

Fig. 5 に抵抗率 $\rho$-表面からの深さ $d$ 特性を示した. $d=0 \mathrm{~mm}$ $0.2 \mathrm{~mm}$ の範囲において $d$ の増加にともなって抵抗率 $\rho$ は減少 して, $d=0.2 \mathrm{~mm}$ においては $\rho$ は最小となった。 さらに, $d=$ $0.2 \mathrm{~mm}-2.0 \mathrm{~mm}$ の範囲では $d$ の増加にともなって $\rho$ は増加し た. また, 素材の密度が高くなると $\rho$ は小さくなった. 3.4 比透磁率 $\mu_{\mathrm{r}}$-表面からの媣さ $d$ 特性

Fig. 6 に比透磁率 $\mu_{\mathrm{r}}$ - 表面からの深さ $d$ 特性を示した. 素材 As-7.00, As-7.25, Hi-7.50では $d=0 \mathrm{~mm} の \mu_{\mathrm{r}}$ は $d=0.3 \mathrm{~mm}$ の $\mu_{\mathrm{r}}$ より小さくなり, $d=0.4 \mathrm{~mm}-1.2 \mathrm{~mm}$ の範囲においては緩や かに減少, $d=1.4 \mathrm{~mm}$ 以降からは急激に小さくなった. また, 素材 $\mathrm{Hi}-7.60$ の $\mu_{\mathrm{r}}-d$ 特性は, $d=0 \mathrm{~mm}-0.4 \mathrm{~mm}$ の範囲では $d$ の 増加により $\mu_{\mathrm{r}}$ は増加しており, $0.4 \mathrm{~mm}-2.0 \mathrm{~mm}$ の範囲では $d$ が増加すると $\mu_{\mathrm{r}}$ は減少した，さらに，素材の密度が高くなる と $\mu_{\mathrm{r}}$ は大きくなった. 


\section{4 考察}

転造加工を施した焼結転造体の表面からの深さに依存する 気孔率 $P$, 残留応力 $\sigma$, 比透磁率 $\mu_{\mathrm{r}}$, 抵抗率 $\rho$ について考察す る. 残留応力は表面からの媣さ $d=0.3 \mathrm{~mm}$ 付近で最も高くな り, $d=0.3 \mathrm{~mm}$ 以降では減少した (Fig. 4). それに対して, 気 孔率は $d=0-0.3 \mathrm{~mm}$ の範囲ではほぼ0\%であり, $d=0.4 \mathrm{~mm}$ 以 降で単調増加した (Fig. 3). 次に抵抗率と比透磁率は, $d=0.3$ $\mathrm{mm}$ 付近で抵抗率が小さくなり, 比透磁率は大きくなった (Fig. 5, Fig. 6).

気孔率が 0\%である表面からの深さ $d=0-0.3 \mathrm{~mm}$ の範囲で 残留応力が変化しているために, 転造加工によって気孔率が $0 \%$ となった以降でも残留応力は変化し続けると考えられる. 同様に，抵抗率と比透磁率は気孔率 $P=0 \%$ である $d=0-0.3$ $\mathrm{mm}$ の範囲でも変化している. そのために, 抵抗率と比透磁 率の残留応力依存性に注目した。

そこで残留応力に依存する気孔率 $P$, 抵抗率 $\rho$, 比透磁率 $\mu_{\mathrm{r}}$ についてまとめた. Fig. 7-9 に素材 As-7.00 と Hi-7.60の気孔 率 $P$, 抵抗率 $\rho$, 比透磁率 $\mu_{\mathrm{r}}$-軸方向の応力 $\sigma_{\mathrm{a}}$ 特性および一次 近似直線をそれぞれ示した，なお同図らは， $d=0.3 \mathrm{~mm}$ 以降 で残留応力が減少して気孔率が大きくなっていく範鿃の特性 に限定した. 測定点はいずれも 8 点であり, 気孔率 $P$, 抵抗 率 $\rho$ の一次近似直線の相関係数は 0.8 以上であった. 比透磁 率 $\mu_{\mathrm{r}}$ は $d=1.4 \mathrm{~mm}$ 以降からは急激に減少したために, 相関係 数は 0.5 となった. Fig. 7,8に示したように残留応力の増加に ともなって, 気孔率と抵抗率は減少した. また, Fig. 9に示し たように比透磁率は残留応力が大きくなると増加して, 残留 応力が $100 \mathrm{MPa}$ より小さなると急激に減少した.

一般論として, 抵抗率は圧縮残留応力が大きくなると減少 して ${ }^{13)}$, 比透磁率は残留応力によって敏感に変化することが 知られている ${ }^{11,12)}$. さらに, 密度が大きくなると, 気孔率と 抵抗率は減少して比透磁率は増加することも知られている ${ }^{12)}$. 本実験では, 表面からの深さ $0.3 \mathrm{~mm}$ 以降では深くなるにとも なって圧縮残留応力は減少して, 気孔率は増加した.また, 抵 抗率は増加して比透磁率は減少した. そのために, 表面から の深さ $0.3 \mathrm{~mm}$ 以降の範囲では残留応力と気孔率の両方が影響 して，抵抗率は増加，比透磁率は減少したと考えられる。渦 電流非破壊検査のための特性が明らかになった。

\section{5 あとがき}

本論文で述べたことをまとめると以下のようになる．

(1)表面からの深さに依存する気孔率, 残留応力, 抵抗率, 比 透磁率

表面からの深さ $d=0-0.3 \mathrm{~mm}$ 範囲における気孔率はほぼ $0 \%$ であり, $d=0.4 \mathrm{~mm}$ 以降において単調増加した. それ に対して, $d=0.3 \mathrm{~mm}$ 付近で最も残留応力が高くなり, $d=$ $0.3 \mathrm{~mm}$ 以降では減少した。次に $d=0.3 \mathrm{~mm}$ 付近で抵抗率 は最も小さくなり, 比透磁率は最も大きくなった.

(2) 残留応力に依存する気孔率, 抵抗率, 比透磁率 表面からの深さ $0.3 \mathrm{~mm}$ 以降では深くなるにともなって圧

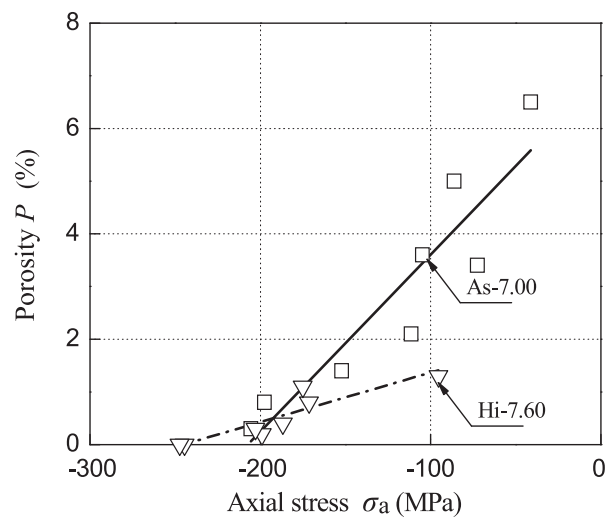

Fig. 7 Porosity-axial stress characteristics as the parameter of As7.00 and $\mathrm{Hi}-7.60$.

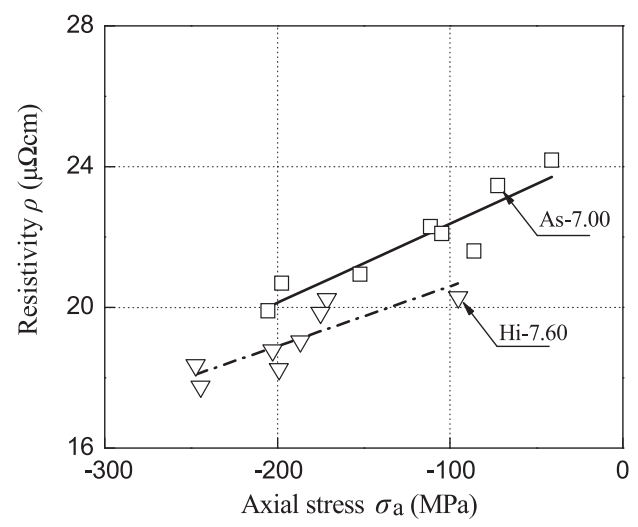

Fig. 8 Resistivity-axial stress characteristics as the parameter of As-7.00 and $\mathrm{Hi}-7.60$.

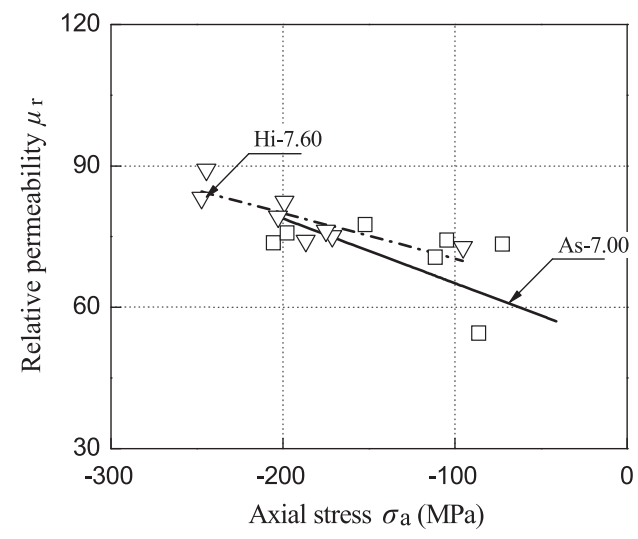

Fig. 9 Relative permeability-axial stress characteristics as the parameter of As-7.00 and $\mathrm{Hi}-7.60$.

縮残留応力は減少して, 気孔率は増加した. また, 抵抗率 は増加して比透磁率は減少した。表面からの深さ $0.3 \mathrm{~mm}$ 以降の範囲では残留応力と気孔率の両方が影響して, 抵 抗率は増加，比透磁率は減少したと考えられる。

\section{文献}

1) H. Miura, H. Tsumori, S. Hamamoto, K. Kawamoto, and S. 
Unami: "Improvement of the Contact Fatigue Strength by Rolling of Sintered Ferrous Alloy Roller-2nd Report-", J. Jpn. Soc. Powder Powder Metallurgy, 57(2010)430-434.

2) T. Takemasu, T. Ozaki, and R. Matsunaga: "Crowning process of P/M gear for automotive transmissions by finish rolling using screw-shaped tool", JSME Int. Journal. Ser. A. Solid Mech. Mater. Eng. Soc. Mech. Engineers, 46(2003)196-201.

3) M. Asti, D. Bassan, and M.F. Pidria: Sintered gears for automotive applications, Metall Ital., 96(2004)37-42.

4) T. Takemasu, T. Koide, Y. Takeda, and T. Shinbutsu: "Accuracy and Fatigue Performance of Finish Rolled Cr-Mo Sintered Steel Gears", Journal of Automotive Engineering, 73 (2008) 1-6.

5) T. Abe, S. Washimi, H. Hashimoto, and T. Kuriyama: "Material Characterization by Ultrasonic Imaging", Materia Japan, 35 (1996)804-809.

6) M. Tanaka and Y. Mitsuhashi: "Surface Layer of the Sintered Steel due to the Milling Operation", The Japan Society for Precision Engineering, 41(1975)808-813.

7) T. Takemasu, T. Koide, Y. Takeda, T. Shinbutsu, D. Kamimura, K. Saito, and S. Nakamura: "Surface Rolling Properties and Surface Durability of $1.5 \mathrm{Cr}-0.2 \mathrm{Mo}$ Sintered Alloy Steel Rollers", J. Jpn. Soc. Powder Powder Metallurgy, 57(2010) 424-429.

8) Y. Kitamura, K. Deguchi, and T. Mizuno: "Measurement of
Porosity of Sintered Gear Using Eddy-current Sensor", Proceedings of the 2010 Japan Industry Applications Society Conference, 2010(2010) 59.

9) T. Mizuno, K. Deguchi, Y. Shimizu, Y. Shimura, Y. Kitamura, T. Takemasu, T. Shinbutsu, S. Amano, H. Yoshikawa, and S. Matsumoto: "Measurement on Porosity of Sintered Steel Using Eddy-Current Sensor", Abstracts of Autumn Meeting of Japan Society of Powder and Powder Metallurgy, 2009(2009)69.

10) The Japanese Society for Non-Destructive Inspe-ction: "Eddy Current Testing III", The Japanese Society for Non-Destructive Inspection, (2003) 1 .

11) K. Kusaka, T. Takesita, and T. Kondo: "Effect of Stress/Strain on Magnetic Properties of Soft Magnetic Materials", J. Jpn. Soc. Powder Powder Metallurgy, 46(1999)666-672.

12) T. Kato, T. Kono, M. Kawamura, and Y. Nakajima: "Magnetic Properties of FeCr System Alloys in Direct and Alternating Field", J. Jpn. Soc. Powder Powder Metallurgy, 40(1993)12461252.

13) I. Endo, H. Kubo, Y. Morioka, and S. Itoh: "Electrical Resistivity Changes of Iron Powder Compacts during Sintering", J. Jpn. Soc. Powder Powder Metallurgy, 26(21979) 195-200.

14) Metal Powder Industries Federation: "MPIF Standard 35, PM Structural Material Section", The Metal Injection Molding Association, (2007)56-57. 